\title{
The protein requirement of infants at the age of about 1 year
}

\author{
By H. CHAN* AND J. C. WATERLOW \\ Medical Research Council Tropical Metabolism Research Unit, \\ University of the West Indies, famaica
}

(Received 8 February 1966-Accepted 3 I May 1966)

\begin{abstract}
I. A study has been made of the protein requirements for maintenance and for growth of children about $\mathrm{I}$ year old who had recovered from malnutrition. 2. The diets used supplied $120 \mathrm{kcal} / \mathrm{kg}$ daily; the sole source of protein was dried skim milk. 3. The average maintenance requirement, measured by nitrogen balance, was found to be $100 \mathrm{mg} \mathrm{N} / \mathrm{kg}$ day. At this level of intake the net protein utilization (NPU) of cow's milk protein approached 100. 4. An intake of $200 \mathrm{mg} \mathrm{N} / \mathrm{kg}$ day was enough to produce normal growth and $\mathrm{N}$ retention. 5 . The amount of $\mathrm{N}$ retained was $2.9 \mathrm{~g} / \mathrm{r} 00 \mathrm{~g}$ weight gain, indicating that no excess of fat was being laid down. 6. These results are in close agreement with theoretical studies of the protein requirement of children at this age.
\end{abstract}

In countries where protein is in short supply the growth of infants tends to fall off at the age of about 6 months. Clinical signs of protein malnutrition appear towards the end of the Ist year or in the 2nd year of life, the average age of onset varying a little according to the local dietary pattern. For every child who becomes clinically ill there are undoubtedly many more in a state of marginal protein malnutrition.

In order that preventive measures can be planned in a rational way it is obviously necessary to know as accurately as possible the protein requirement of children at about I year. Unfortunately there is very little factual information about this. As recently as 2 years ago Hegsted (1964) wrote: 'Few, if any, studies have been done to determine experimentally the minimal protein needs of children and infants....' Estimates have been made based on theoretical grounds (Hegsted, r957, I959, I964; WHO, 1965 ), but these need to be checked by observation and experiment. This was the objective of the work reported here.

The study was divided into two parts: measurement of the protein requirement for maintenance, and for growth. The criteria used were the classical ones of nitrogen balance and weight gain. The subjects were male infants recovering or fully recovered from protein-calorie malnutrition. We believe that a child can be regarded as recovered when he has regained the ideal weight for a child of the same height. The ideal weight is taken as the 5oth percentile for US children (Nelson, 1954). In principle, since the purpose was to determine the amount of protein needed to keep a child in a normal state of nutrition, all the trials should have been done on fully recovered subjects of closely uniform ages. Although this was not always practicable, in the growth studies the subjects had as far as possible regained their normal weight for height (see Table 2). The maintenance requirement per $\mathrm{kg}$, represented by the obligatory loss of $\mathrm{N}$ in

* Present address: Department of Chemical Pathology, St Mary's Hospital, London, W2, England. 
urine and faeces, may not be much affected by the state of nutrition, but we know from previous experience that undernourished children, if given an adequate $\mathrm{N}$ intake, can grow at a rate that is much faster than normal (Waterlow, 196r). Studies on depleted children might therefore give an unfairly low estimate of the protein requirement for normal growth, if the depleted child can utilize $\mathrm{N}$ more efficiently than the normal.

\section{EXPERIMENTAL}

\section{Maintenance study}

$\mathrm{N}$ balances were made on seventeen infants at varying stages of recovery, of whom ten were studied twice and one three times. Between studies these children received a milk mixture of the following composition per l.: dried skim milk $60 \mathrm{~g}$, sucrose $3 \circ \mathrm{g}$, arachis oil $9 \circ \mathrm{ml}$. This provided $3-4 \mathrm{~g}$ protein $/ \mathrm{kg}$ daily, and produced rapid weight gains. The characteristics of the children at the time of study are shown in Table I. In the initial balance periods the aim was to give about $200 \mathrm{mg} \mathrm{N} / \mathrm{kg}$ daily. In the later balance periods the protein intake was progressively reduced until $\mathrm{N}$ balance was just maintained. Each balance study consisted of an equilibrium period of at least 3 days on the diet, followed by three $48 \mathrm{~h}$ collections of urine and faeces separated by intervals of $\mathrm{I}$ or 2 days. Body-weights were measured daily on a scale accurate to $\mathrm{I} \mathrm{g}$.

\section{Growth study}

Twelve children who had regained, or nearly regained, their normal weight for height were given daily for 3 weeks a diet supplying $120 \mathrm{kcal} / \mathrm{kg}$ and from 275 to $190 \mathrm{mg} \mathrm{N} / \mathrm{kg}$. Two $48 \mathrm{~h} \mathrm{~N}$ balances were made in the middle week.

If conditions are carefully standardized, we believe that 3 weeks is a long enough time for measurement of weight gain to have some meaning. Analysis of the weight gains over a 3-week period in an unselected series of malnourished infants treated in our ward showed a significant relationship between weight gain, calorie intake and protein intake (Waterlow, 1961).

\section{Diets}

In both the maintenance and growth studies the diet consisted of a mixture containing (g/l.): dried skim milk $1_{5-3} 3$, cane sugar $100-50$, maize starch 25 , arachis oil 60 . It contained I 100-1000 kcal/l. and was given in amounts designed to supply

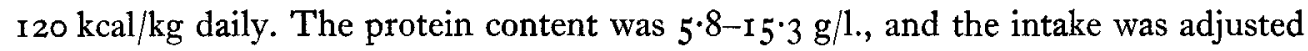
to the desired level by varying the proportions of skim milk and sugar. The milk powder was manufactured in New Zealand, and had a net protein utilization (NPU) (standardized), measured by D. S. Miller of Queen Elizabeth College on the rat, of 85. Orange juice and supplements of $B$ vitamins were given daily. Calorie intakes were calculated by the standard factors: $4 \mathrm{kcal} / \mathrm{g}$ for carbohydrate and protein, $9 \mathrm{kcal} / \mathrm{g}$ for fat.

\section{Methods}

The methods of collection of urine and stools, of measurement of food intake and of $\mathrm{N}$ determination were those described in an earlier report (Waterlow \& Wills, 
1960). Foods, urine and stools were analysed for $\mathrm{N}$ in duplicate by the micro-Kjeldahl method.

\section{Calculation of $N P U$}

NPU is calculated in the same way as the classical biological value, except that retention is related to $\mathrm{N}$ intake and not to $\mathrm{N}$ absorbed. Thus

$$
\begin{aligned}
\mathrm{NPU} & =\frac{\mathrm{N} \text { retained on test } \operatorname{diet}-\mathrm{N} \text { retained on protein-free diet }}{\mathrm{N} \text { intake }} \\
& =\frac{\mathrm{N} \text { retained on test diet }+ \text { endogenous } \mathrm{N} \text { output }}{\mathrm{N} \text { intake }}
\end{aligned}
$$

The regression line in Fig. I shows that the endogenous $\mathrm{N}$ output (intercept on $y$ axis when $x=0$ ) is almost exactly equal to the maintenance requirement (intercept on $x$ axis when $y=0$ ); i.e. the slope of the line is $\mathrm{I}$. Since the maintenance requirement has been estimated directly, whereas the endogenous output is only obtained by extrapolation, we have calculated NPU as

$$
\frac{\mathrm{N} \text { retained }+\mathrm{N} \text { required for maintenance }}{\mathrm{N} \text { intake }}
$$

\section{RESULTS}

The characteristics of the children, and their $\mathrm{N}$ intakes and retentions, are shown in Table I for the maintenance study and in Table 2 for the growth study. The results, which are plotted together in Fig. $\mathrm{I}$, suggested that the relationship of $\mathrm{N}$ retention to $\mathrm{N}$ intake was curvilinear, as in theory it should be (Allison \& Anderson, I945; Allison, Anderson \& Seeley, I946; Hegsted \& Chang, 1965).

For ease of analysis it seemed justifiable to treat the results in two groups, and to draw two regression lines, corresponding to intakes above and below $180 \mathrm{mg} / \mathrm{kg}$ daily. This value was chosen arbitrarily, because the curve seemed to bend in the region of daily $\mathrm{N}$ intakes between $\mathrm{I} 8 \mathrm{o}$ and $200 \mathrm{mg} / \mathrm{kg}$.

\section{Maintenance study}

The regression line $M-M^{\prime}$ represents the results of all the maintenance balances, except three in which the intakes were more than $\mathrm{I} 80 \mathrm{mg} \mathrm{N} / \mathrm{kg}$ daily. The regression line is: $y=0.97 x-97$, where $x=$ intake and $y=$ retention in $\mathrm{mg} \mathrm{N} / \mathrm{kg}$ day. The line cuts the abscissa at an intake of $100 \mathrm{mg} \mathrm{N} / \mathrm{kg}$ day, and this, therefore, is the estimate of the average maintenance requirement. The slope of the regression line represents the NPU. It is apparent that at these low levels of intake the efficiency of $\mathrm{N}$ utilization was virtually $100 \%$. The standard deviation of the amounts of $\mathrm{N}$ retained was I I $\mathrm{mg}$, or rather less than $10 \%$ of the average intake in the group.

From the results of our previous work it was expected that at a given level of intake the more severely malnourished children would retain more $\mathrm{N}$ (Waterlow \& Wills, 1960). In the study now presented this was not so: there was no consistent relation between the degree of weight deficit and the efficiency of $\mathrm{N}$ retention (Table 3 ). We are unable to explain the lower $\mathrm{N}$ retentions in group $\mathrm{E}$, since the children took 


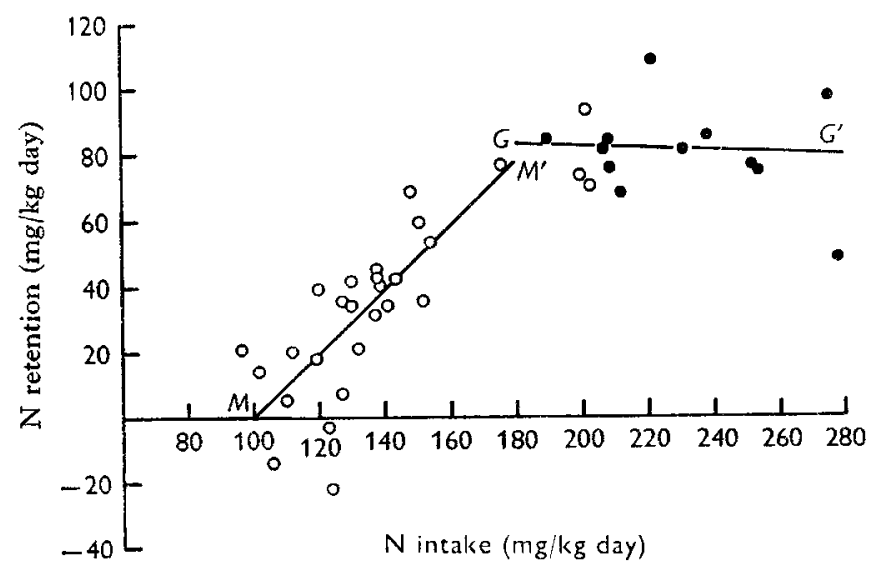

Fig. I. Nitrogen retention by infants about I year old at various levels of $\mathrm{N}$ intake. 0 , maintenance study; $\bullet$, growth study. $M-M^{\prime}, y=0.97 x-97 ; G-G^{\prime}, y=-0.044 x+91$, where $x=$ intake and $y=$ retention in $\mathrm{mg} / \mathrm{kg}$ day.

Table $\mathrm{I}$. Nitrogen retention and weight change of infants at intakes between 100 and $200 \mathrm{mg} \mathrm{N} / \mathrm{kg}$ day

\begin{tabular}{|c|c|c|c|c|c|c|c|c|}
\hline Subject* & $\begin{array}{c}\text { Age† } \\
\text { (months) }\end{array}$ & $\begin{array}{c}\text { Days } \\
\text { after } \\
\text { admission }\end{array}$ & $\begin{array}{l}\text { Weight } \dagger \\
\quad(\mathrm{kg})\end{array}$ & $\begin{array}{c}\% \text { of } \\
\text { normal } \\
\text { weight } \\
\text { for height }\end{array}$ & $\begin{array}{c}\% \text { of } \\
\text { normalt } \\
\text { weight } \\
\text { for age }\end{array}$ & $\begin{array}{c}\mathrm{N} \text { intake } \\
(\mathrm{mg} / \mathrm{kg} \text { day })\end{array}$ & $\begin{array}{l}\text { N retained } \\
\text { (mg/ } \\
\mathrm{kg} \text { day) }\end{array}$ & $\begin{array}{r}\text { Weight } \\
\text { change } \\
\text { (g/kg day }\end{array}$ \\
\hline $\mathrm{EN}_{2}$ & 14 & $3^{8}$ & $8 \cdot 4$ & 85 & 80 & 203 & 70 & $+I \cdot x$ \\
\hline $\mathrm{EB}$ I & I I $\frac{1}{2}$ & 9 & $7 \cdot 0$ & 80 & 70 & 202 & 93 & $+3 \cdot 0$ \\
\hline EN I & I3 & IO & $7 \cdot 25$ & 75 & 70 & 200 & 73 & $-6 \cdot 6$ \\
\hline $\mathrm{EB}_{2}$ & $12 \frac{1}{2}$ & 37 & $8 \cdot 6$ & 95 & 85 & I 76 & 76 & $+3 \cdot I$ \\
\hline $\mathrm{JG} I$ & 6 & 25 & $6 \cdot 2$ & 93 & $8_{3}$ & 154 & 53 & o \\
\hline $\mathrm{CW}_{\mathrm{I}}$ & $10 \frac{1}{2}$ & 18 & $4 \cdot 5$ & 68 & 47 & I 52 & 35 & $-6 \cdot I$ \\
\hline DR 2 & 19 & 39 & $7 \cdot 8$ & $8_{3}$ & 68 & I 51 & 59 & $+\mathrm{I} \cdot 55$ \\
\hline CT I & $19 \frac{1}{2}$ & 27 & $8 \cdot 0$ & 75 & 69 & 148 & 68 & +5.05 \\
\hline DR I & I $8 \frac{1}{2}$ & 19 & $7 \cdot 4$ & 80 & 65 & I 44 & 42 & -5.65 \\
\hline NG & 19 & 19 & $6 \cdot 4$ & 85 & 63 & I 4I & 34 & $+x \cdot 95$ \\
\hline $\mathrm{AD}_{\mathrm{I}}$ & I $5 \frac{1}{2}$ & 7 & $5^{\circ} 0$ & 68 & 46 & 139 & 40 & $-x \cdot 0$ \\
\hline $\mathrm{CW}_{2}$ & $12 \frac{1}{2}$ & 59 & $6 \cdot 4$ & 85 & 63 & $13^{8}$ & 43 & $+\mathbf{I} \cdot \mathbf{I}$ \\
\hline JG 2 & $6 \frac{1}{2}$ & 42 & $6 \cdot 2$ & 93 & 83 & I 38 & 45 & $+1 \cdot 3$ \\
\hline AS & $15 \frac{1}{2}$ & 42 & $8 \cdot 5$ & 88 & 80 & 137 & $3 \mathbf{I}$ & $+r \cdot 2$ \\
\hline $\mathrm{GW}_{2}$ & 17 & 53 & $7 \cdot 8$ & 90 & 70 & 132 & $2 \mathrm{I}$ & -3.5 \\
\hline DH & 13 & 2 I & $8 \cdot 7$ & 80 & 85 & 130 & 34 & $-1 * 7$ \\
\hline CT 2 & 20 & 48 & $9 \cdot 0$ & 83 & 77 & 130 & $4 I$ & $+3 \cdot 2$ \\
\hline GW i & 16 & 25 & $6 \cdot 2$ & 78 & 57 & 127 & 7 & $-3 \cdot 8$ \\
\hline FW & 12 & I 3 & $6 \cdot 0$ & 75 & 60 & 127 & 35 & $-2 \cdot I$ \\
\hline ER I & 10 & 20 & $5 \cdot 4$ & 65 & 57 & 124 & -22 & 0 \\
\hline $\mathrm{SR}$ & 6 & $9 I$ & $4 \cdot 3$ & 95 & 57 & 123 & -3 & $-4 \cdot 6$ \\
\hline $\mathrm{AD}_{2}$ & $16 \frac{1}{2}$ & 35 & 5.9 & 75 & 53 & 120 & 39 & $-2 \cdot 2$ \\
\hline ER 2 & $\operatorname{II} \frac{1}{2}$ & 55 & $6 \cdot 8$ & 65 & $5^{8}$ & I 19 & I 8 & 0 \\
\hline $\operatorname{OS} 2$ & I 3 & 44 & $7 \cdot 5$ & 80 & 75 & II 2 & 20 & $+x \cdot 9$ \\
\hline NW & $12 \frac{1}{2}$ & 9 & $4 \cdot 6$ & $5^{8}$ & 46 & I IO & 5 & -0.9 \\
\hline $\mathrm{HMcG}$ & 17 & 27 & $8 \cdot 2$ & 75 & 75 & 106 & -14 & $-5 \cdot 2$ \\
\hline $\mathrm{AD}_{3}$ & $17 \frac{1}{2}$ & 67 & $7 \cdot 0$ & 85 & 62 & 102 & 14 & $-2 \cdot 4$ \\
\hline OS I & 12 & 20 & $7 \cdot 5$ & 80 & 75 & 97 & 21 & $-2 \cdot 2$ \\
\hline
\end{tabular}

* Balances listed in order of decreasing intake. Numbers refer to repeated balances on the same subject. $\uparrow$ At beginning of equilibrium period.

I 'Normal' weights and heights taken as the 5oth percentile for boys in the tables of Nelson (I954). 
their food well. It may simply be due to the small number of subjects and chance variation.

Not very much significance can be attached to the changes in body-weight shown in the last column of Table $\mathrm{I}$. These values represent the average weight change observed over the ro days or so that are required for the balance study together with the preliminary feeding period. Because of the daily fluctuations which are always found, this time is too short for a significant measurement of weight change, particularly in infants who are being restrained for part of the time. These figures are presented to show that on the average there were small losses of weight at the lower levels of intake.

\begin{tabular}{|c|c|c|c|c|c|c|c|c|c|}
\hline Subject & $\begin{array}{c}\text { Age* } \\
\text { (months) }\end{array}$ & $\begin{array}{l}\text { Weight* } \\
\text { (kg) }\end{array}$ & $\begin{array}{c}\% \text { of } \\
\text { expected } \\
\text { weight for } \\
\text { height* }\end{array}$ & $\begin{array}{l}\% \text { of } \\
\text { expected } \\
\text { height for } \\
\text { age* }\end{array}$ & $\begin{array}{c}\mathrm{N} \text { intake } \\
(\mathrm{mg} / \\
\mathrm{kg} \text { day })\end{array}$ & $\begin{array}{c}\mathrm{N} \\
\text { retained } \\
(\mathrm{mg} / \\
\mathrm{kg} \text { day })\end{array}$ & $\begin{array}{c}\text { Weight } \\
\text { gain } \\
\text { (g/kg day) }\end{array}$ & $\begin{array}{c}N \\
\text { retained } \\
\text { (g/roo g wt } \\
\text { gain) }\end{array}$ & NPI \\
\hline $\mathrm{JC}$ & $17 \frac{3}{4}$ & $8 \cdot 5^{I}$ & 90 & 88 & 278 & 48 & $2 \cdot$ II & $2 \cdot 28$ & 53 \\
\hline $\mathrm{DM}$ & $12 \frac{1}{2}$ & $9 \cdot 64$ & IOI & 96 & 275 & 97 & $2 \cdot 40$ & 4.03 & 71 \\
\hline $\mathrm{HG}$ & 94 & $5 \cdot 84$ & 102 & 86.5 & 254 & 84 & $3 \cdot 34$ & $2 \cdot 51$ & 72 \\
\hline $\mathrm{LN}$ & $18 \frac{1}{4}$ & $7 \cdot 34$ & $97 \cdot 5$ & 89.5 & 252 & 86 & 2.50 & $3 \cdot 44$ & $73 \cdot 5$ \\
\hline MG & $9 \frac{3}{4}$ & $6 \cdot 30$ & 88 & 90 & $23 \mathrm{I}$ & $8 \mathbf{I}$ & $4 \cdot 00$ & 2.02 & 78 \\
\hline $\mathrm{CB}$ & $9 \frac{3}{4}$ & 6.50 & 102 & 87 & 238 & 85 & $2 \cdot 80$ & 3.04 & 78 \\
\hline EM & $25 \frac{1}{4}$ & $9 \cdot 70$ & 93 & $88 \cdot 5$ & 222 & 108 & $3 \cdot 3 \mathrm{I}$ & $3 \cdot 26$ & 93.5 \\
\hline SM & $2 \mathrm{I}$ & $7 \cdot 5^{2}$ & $88 \cdot 5$ & $82 \cdot 5$ & 212 & 68 & 3.06 & $2 \cdot 22$ & $79 \cdot 5$ \\
\hline NS & I $3 \frac{1}{2}$ & $7 \cdot 90$ & $97 \cdot 5$ & 89 & 209 & 75 & $I \cdot 75$ & $4 \cdot 27$ & 84 \\
\hline AW & $10 \frac{1}{4}$ & $7 \cdot 00$ & 98 & 89 & 209 & 84 & $2 \cdot 76$ & 3.05 & 88 \\
\hline EG & $6 \frac{1}{2}$ & $5 \cdot 85$ & I I I & $87 \cdot 5$ & 207 & 81 & 4.00 & $2 \cdot 02$ & 87.5 \\
\hline $\mathrm{LC}$ & $I I \frac{1}{4}$ & $7 \cdot 34$ & $97 \cdot 5$ & 89.5 & 190 & 84 & 3.02 & $2 \cdot 78$ & $96 \cdot 5$ \\
\hline
\end{tabular}

* At beginning of study.

+ Calculated as $[(\mathrm{N}$ required for maintenance $+\mathrm{N}$ retained $) / \mathrm{N}$ intake $] \times 1$ oo. Maintenance requirement taken as $100 \mathrm{mg} \mathrm{N} / \mathrm{kg}$ day.

Table 3. Maintenance balances: comparison of expected and observed $N$ retention by children with different degrees of weight deficit

\begin{tabular}{|c|c|c|c|c|c|c|}
\hline \multirow[b]{2}{*}{ Group } & \multirow{2}{*}{$\begin{array}{l}\text { No, of } \\
\text { children }\end{array}$} & \multicolumn{2}{|c|}{$\begin{array}{c}\text { Weight } \\
\text { (\% of expected weight } \\
\text { for height) }\end{array}$} & \multicolumn{2}{|c|}{$\mathrm{N}$ retention $(\mathrm{mg} / \mathrm{kg}$ day) } & \multirow{2}{*}{$\begin{array}{l}\text { Mean } \\
\text { no. of days } \\
\text { since } \\
\text { admission }\end{array}$} \\
\hline & & Mean & Range & Expected* & Observed & \\
\hline A & 5 & $94 \cdot 5$ & $90-100$ & $44 \cdot 5$ & $3^{8 \cdot 5}$ & 50 \\
\hline B & 5 & 86.0 & $85-89$ & $3^{8} \cdot 5$ & $36 \cdot 0$ & 50 \\
\hline $\mathrm{C}$ & 7 & $8 I \cdot 0$ & $80-84$ & 39 & 44.0 & 30 \\
\hline $\mathbf{D}$ & 6 & $75 \cdot 5$ & $75-79$ & 38 & $34 \cdot 5$ & 23 \\
\hline $\mathrm{E}$ & 5 & 66 & $5^{8-72}$ & 33 & $18 \cdot 5$ & $14 \cdot 5$ \\
\hline
\end{tabular}

\section{Growth study}

Although the number of subjects was not large, the results in Table 2 suggest that a daily intake of $200 \mathrm{mg} \mathrm{N} / \mathrm{kg}$ was enough to secure satisfactory weight gain. The mean daily rate of gain in the six children with the lowest intakes was $3 \mathrm{~g} / \mathrm{kg}$. This is much higher than the rate of gain in a normal child growing normally: from 9 to 
12 months the average rate of gain is $1.2 \mathrm{~g} / \mathrm{kg}$ day, falling to about $0.7 \mathrm{~g} / \mathrm{kg}$ day in the next 6 months (Nelson, I954).

On average $2.9 \mathrm{I} \mathrm{g} \mathrm{N} / \mathrm{I} 00 \mathrm{~g}$ weight gain were retained. This suggests that there was little if any deposition of excess fat. The calorie intake of $120 \mathrm{kcal} / \mathrm{kg}$ daily, although on the high side, was not excessive for this rate of growth. A reasonable allowance for basal metabolism, activity and faecal loss is $90 \mathrm{kcal} / \mathrm{kg}$ day (Clements, 1949; Montgomery, 1962). To this must be added about $10 \mathrm{kcal} / \mathrm{g}$ weight gain as the energy requirement for the formation. of new tissue (Waterlow, r96I), making a total of $120 \mathrm{kcal}$.

The regression line $G-G^{\prime}$ (Fig. I) drawn through the points corresponding to $\mathrm{N}$ intakes of more than $180 \mathrm{mg} / \mathrm{kg}$ day has the formula: $y=-0.044^{x}+9 \mathrm{I}$, where $x=$ intake and $y=$ retention in $\mathrm{mg} \mathrm{N} / \mathrm{kg}$ day. According to this relationship, at an intake of $200 \mathrm{mg} \mathrm{N} / \mathrm{kg}$ day, the expected retention would be 82 , and at an intake of 300 it would be 78 . Thus over this range of intake the retention was virtually constant, within the limits of error, at about $80 \mathrm{mg} \mathrm{N} / \mathrm{kg}$ day.

\section{DISCUSSION}

In the maintenance study, the finding that the variation in the amounts of $\mathrm{N}$ retained was less than $10 \%$ of the average intake in the group supports the recommendation of the WHO/FAO Expert Group (WHO, 1965) that a margin of safety of $20 \%$ should cover the great majority of individual variations in requirement. The fact that in this group weight deficit was not related to the efficiency of $\mathrm{N}$ retention might have been due to the much lower intakes compared with those reported in our previous study (Waterlow \& Wills, I960), so that even fully recovered children retained a large proportion of ingested $\mathrm{N}$.

The most likely explanation for the high rates of weight gain in the children in the growth study is that, although the children had substantially regained their normal weight for height, they were still well below the normal height for their age. On the average, the height of each child corresponded to an age of 6 months less than his chronological age (average 'height age' 8 months, compared with chronological age I3.7 months). A normal child between 6 and 9 months should be gaining weight at the rate of $2 \mathrm{~g} / \mathrm{kg}$ day. If in addition these children were showing some degree of 'catch-up' growth, weight gains of $3 \mathrm{~g} / \mathrm{kg}$ day do not seem excessive. The finding that the absolute $\mathrm{N}$ retention reaches a plateau, although reasonable on theoretical grounds, is unusual. It has often been observed, in balance studies on normal children, that the higher the intake the greater the apparent retention. Wallace (1959) has attributed this to the cumulative errors of the balance technique.

If the obligatory loss in urine and faeces is taken as $97 \mathrm{mg} \mathrm{N} / \mathrm{kg}$ day, and the retention is $80 \mathrm{mg} \mathrm{N} / \mathrm{kg}$ day, it is obvious that the NPU must fall, from a value of $88.5 \%$ at an intake of $200 \mathrm{mg} / \mathrm{kg}$ to $59 \%$ at an intake of $300 \mathrm{mg} / \mathrm{kg}$. It seems from this that an intake of $200 \mathrm{mg} \mathrm{N} / \mathrm{kg}$ day would be a suitable level for tests on young children of the comparative nutritive value of different protein foods. In many such investigations higher levels have been used, which are likely to give erroneous results. 
At low levels of intake the efficiency of utilization of cow's milk protein was surprisingly high. It seems that this efficiency is not the prerogative of the child who is clinically malnourished. A further illustration of this is that when infants were transferred from a high to a low protein intake the net loss of $\mathrm{N}$ during the period of adaptation was not influenced by the degree of malnutrition, and was in all subjects much less than in the adult (Chan, to be published).

If, in infants at I year, a daily intake of $200 \mathrm{mg} \mathrm{N} / \mathrm{kg}$, corresponding to $\mathrm{I} \cdot 25 \mathrm{~g}$ protein with NPU of about 90 , can support growth at twice the normal rate, a fortiori it should be adequate for normal growth, and it is possible that even less would be enough. It is of interest to compare this result obtained by direct observation with the previous estimates for the protein requirement of the infant at I year derived theoretically by Hegsted (1957, 1959, I964) and by the WHO/FAO Expert Group (WHO, I965).

All these calculations start from an estimate of the 'basal' $\mathrm{N}$ output on a protein-free diet. The term 'endogenous' is no longer suitable, since no absolute distinction can be made between endogenous and exogenous metabolism. 'Obligatory' is preferable. By 'basal' is meant the obligatory loss measured before there has been significant depletion of body protein, i.e. measured after $3^{-6}$ days on a protein-free diet (see WHO, 1965). Hegsted (1957, 1959, 1964) bases his calculations on the relationship: endogenous urinary $\mathrm{N}=146 \times$ weight $^{0 \cdot 72}$, derived from the values tabulated by Brody (1945). In a ro $\mathrm{kg}$ child I year old the basal urinary $\mathrm{N}$ calculated with this formula would be $76 \mathrm{mg} / \mathrm{kg}$ day. To this must be added the basal faecal loss, which may be taken as about $30 \mathrm{mg} \mathrm{N} / \mathrm{kg}$ day (Waterlow \& Wills, 1960; Fomon, deMaeyer \& Owen, 1965), giving a total by the two routes of 100-1 10 $\mathrm{mg} \mathrm{N} / \mathrm{kg}$ day. The estimate of basal loss used by the WHO/FAO Expert Group was $70 \mathrm{mg} \mathrm{N} / \mathrm{kg}$ day. This value was obtained by extrapolation from the results of earlier balance studies in which the intakes were mostly between 300 and $500 \mathrm{mg} \mathrm{N} / \mathrm{kg}$ day. This method of estimation is not very satisfactory; however, Fomon et al. (1965) by direct measurements on infants aged $4 \frac{1}{2}-6$ months on a very low intake of protein also arrived at a value of about $70 \mathrm{mg} \mathrm{N} / \mathrm{kg}$ day for the basal loss in urine and faeces.

It seems, therefore, that the results obtained by direct measurement, by extrapolation and by calculation from an empirical formula are in general agreement that the basal $\mathrm{N}$ loss of infants aged 6-I 8 months lies within the range 70-100 $\mathrm{mg} \mathrm{N} / \mathrm{kg}$ day. This range is the same as that found for younger infants (Fomon, 196r), older children and adults. For estimating requirements, it is safer to take the upper level. If to this are added the needs for growth and maturation, sweat loss and stress, as was done in the WHO/FAO report (WHO, I965), the requirement at I year would be about $\mathrm{I} 60 \mathrm{mg} \mathrm{N} / \mathrm{kg}$ day. 'To this must be added $20 \%$ to cover individual variations, giving a total of $192 \mathrm{mg} \mathrm{N}$ or $\mathrm{I} \cdot 2 \mathrm{~g}$ reference protein (NPU 100 ). If the NPU is 90 , the calculated requirement becomes $\mathrm{I} \cdot 33 \mathrm{~g}$ protein $/ \mathrm{kg}$ day.

The observations reported here confirm that this level of intake does in fact satisfy the child's requirement. For the reasons already discussed, this estimate, to the extent that it is in error, is likely to be too high rather than too low. 
We wish to record our gratitude to the World Health Organization for a research grant in support of this work, and to Dr V. N. Patwardhan, Chief of the Nutrition Division, WHO, for his interest and encouragement. We thank Mr D. S. Miller of Queen Elizabeth College, University of London, for measuring the NPU of the milk powder.

\section{REFERENCES}

Allison, J. B. \& Anderson, J. A. (1945). F. Nutr. 29, 413.

Allison, J. B., Anderson, J. A. \& Seeley, R. D. (r946). Ann. N.Y. Acad. Sci. 47, 245.

Brody, S. (1945). Bioenergetics and Growth. New York: Reinhold Publishing Corp.

Clements, F. W. (1949). Infant Nutrition: its Physiological Basis. Bristol: J. Wright and Sons.

Fomon, S. J. (196r). Publs natn. Res, Coun., Wash. no. 843, p. 343.

Fomon, S. J., deMaeyer, E. M. \& Owen, G. M. (1965). F. Nutr. 85, 235.

Hegsted, D. M. (1957). F. Am. diet. Ass. 33, 225.

Hegsted, D. M. (1959). Fedn Proc. Fedn Am. Socs exp. Biol. 18, 1130.

Hegsted, D. M. (1964). In Mammalian Protein Metabolism. Vol. 2, p. 135. [H. N. Munro and J. B. Allison, editors.] New York and London: Academic Press Inc.

Hegsted, D. M. \& Chang, Y. O. (1965). F. Nutr. 87, 19.

Montgomery, R. D. (1962). F. clin. Invest. 4I, I653.

Nelson, W. E. (I 954). Textbook of Paediatrics. Philadelphia and London: W. B. Saunders Co.

WHO (1965). Tech. Rep. Ser. Wld Hlth Org. no. 301.

Wallace, W. M. (1959). Fedn Proc. Fedn Am. Socs exp. Biol. 18, 1125.

Waterlow, J. C. (1961). F. trop. Pediat. 7, 16.

Waterlow, J. C. \& Wills, V. G. (1960). Br. F. Nutr. 14, I83. 